Erratum

\title{
Erratum to "Expression Profiling of Genes Related to Endothelial Cells Biology in Patients with Type 2 Diabetes and Patients with Prediabetes"
}

\author{
Sara Moradipoor, ${ }^{1}$ Patimah Ismail, ${ }^{1}$ Ali Etemad, ${ }^{1}$ Wan Aliaa Wan Sulaiman, ${ }^{2}$ \\ Salma Ahmadloo, ${ }^{1}$ and Somayeh Khazaei ${ }^{1}$ \\ ${ }^{1}$ Department of Biomedical Sciences, Faculty of Medicine and Health Sciences, Universiti Putra Malaysia, Serdang, Selangor, Malaysia \\ ${ }^{2}$ Department of Medicine, Faculty of Medicine and Health Sciences, Universiti Putra Malaysia, Serdang, Selangor, Malaysia \\ Correspondence should be addressed to Ali Etemad; etal1900@gmail.com
}

Received 5 January 2017; Accepted 15 January 2017; Published 15 February 2017

Copyright $\odot 2017$ Sara Moradipoor et al. This is an open access article distributed under the Creative Commons Attribution License, which permits unrestricted use, distribution, and reproduction in any medium, provided the original work is properly cited.

In the article titled "Expression Profiling of Genes Related to Endothelial Cells Biology in Patients with Type 2 Diabetes and Patients with Prediabetes" [1], Dr. Somayeh Khazaei was missing from the authors' list. The corrected authors' list is shown above.

\section{References}

[1] S. Moradipoor, P. Ismail, A. Etemad, W. A. Wan Sulaiman, and S. Ahmadloo, "Expression profiling of genes related to endothelial cells biology in patients with type 2 diabetes and patients with prediabetes," BioMed Research International, vol. 2016, Article ID 1845638, 12 pages, 2016. 

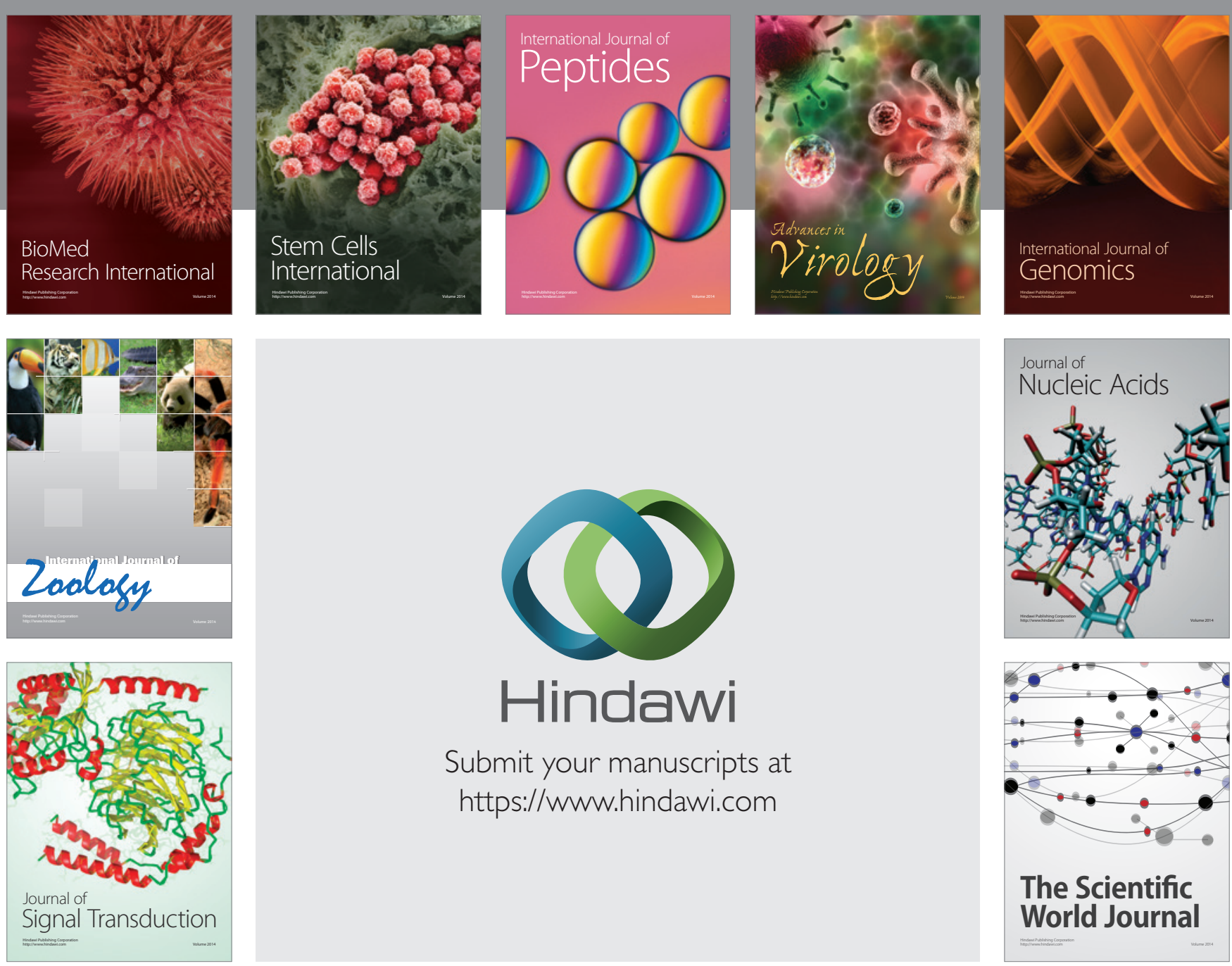

Submit your manuscripts at

https://www.hindawi.com
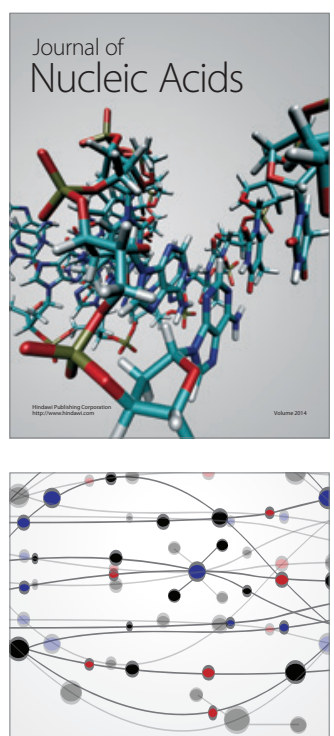

The Scientific World Journal
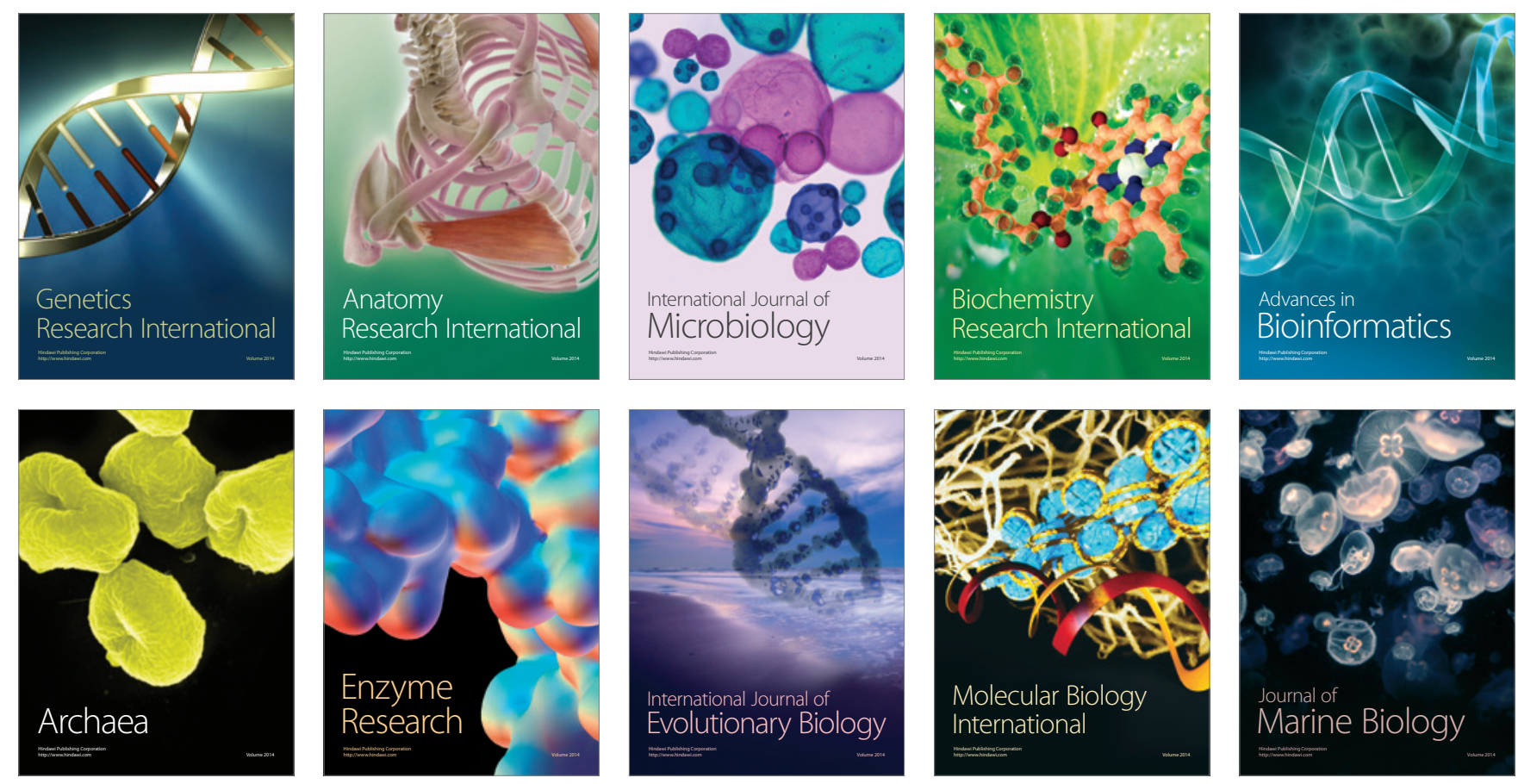